\title{
Miasto-palimpsest. Semiotyczna interpretacja Czerniowiec
}

\author{
City-Palimpsest. A semiotic interpretation \\ of Chernivtsi
}

\author{
|| $\begin{aligned} & \text { Rafał Koschany } \\ & \text { Uniwersytet im. Adama Mickiewicza w Poznaniu }\end{aligned}$
}

\begin{abstract}
The article is an attempt of a semiotic interpretation of the phenomenon of Ukrainian city, Chernivtsi. The methodological context is the tradition of the cultural semiotics (especially the Tartu-Moscow school of semiotics), as well as its current continuations (e.g. sociosemiotics or visual studies). Thanks to the combination of these perspectives, the analysis of the city as a sign system is not limited to its history, but also to the completely contemporary situation of the city, which would like to play anew role of an important multicultural center of Europe and engage various entities for this purpose (politicians, artists, inhabitants, tourists but also city researchers).

The central concept of considerations is palimpsest, understood as a multi-layered text of the city, but above all as a vivid text. The semiotic analysis of the city-palimpsest is based on reading the signs of its past, but also on the interpretation of the continuous writing of new signs, visible both in urban space and narratives about the city created today - touristic, marketing, political or literary (with particular emphasis on The International Poetry Festival "Meridian Czernowitz"). The city-palimpsest is thus a city understood as a work of art, which on the one hand requires the interpretation of senses encoded in it, and on the other hand it updates these senses in a different way in the process of rebuilding its brand.
\end{abstract}

Key words: interpretation, semiotics, literary tourism, literary festivals

Streszczenie: Artykuł stanowi próbę semiotycznej interpretacji fenomenu ukraińskich Czerniowiec. Kontekstem metodologicznym jest zarówno tradycja semiotyki kultury (zwłaszcza tartusko-moskiewska szkoła semiotyczna), jak i współczesne jej kontynuacje (np. socjosemiotyka czy studia wizualne). Dzięki połączeniu tych perspektyw analiza miasta jako systemu znaków nie ogranicza się wyłącznie do jego historii, ale także do zupełnie współczesnej sytuacji miasta, które chciałoby odgrywać na nowo rolę ważnego ośrodka wielokulturowej Europy i angażuje w tym celu rozmaite podmioty (politycy, artyści, mieszkańcy, turyści, ale także badacze miasta).

Pojęcie centralne rozważań stanowi palimpsest, rozumiany jako wielowarstwowy tekst miasta, ale przede wszystkim jako tekst żywy. Semiotyczna analiza miasta-palimpsestu polega bowiem na odczytywaniu znaków jego przeszłości, ale także na interpretacji ciągłego pisania znaków nowych, widocznych zarówno w przestrzeni miejskiej, jak 
i w narracjach o mieście tworzonych dzisiaj - turystycznych, marketingowych, politycznych czy literackich (ze szczególnym uwzględnieniem Międzynarodowego Poetyckiego Festiwalu Meridian Czernowitz). Miasto-palimpsest jest zatem miastem rozumianym jako swoiste dzieło sztuki, które - z jednej strony - wymaga interpretacji zaszyfrowanych w nim sensów, z drugiej - w rozmaity sposób aktualizuje te sensy w procesie ponownego budowania swej marki.

Słowa kluczowe: interpretacja, semiotyka, turystyka literacka, festiwale literackie

\section{Czytanie miejskiego palimpsestu: tekst i kontekst}

Palimpsest to rękopis, z którego pierwotny tekst został zmazany, dzięki czemu powstało miejsce na nowy. Niedoskonałe techniki ścierania oraz różnego rodzaju materiały używane do produkcji rękopisu sprawiały, że spod nowego zapisu najczęściej prześwitywał ten pierwotny, który za pomocą różnych chemicznych procedur starano się odczytać. Niejednokrotnie odzyskiwano w ten sposób sam tekst, ale również jego bardzo szeroki kontekst - historyczną, kulturową i antropologiczną wiedzę o przeszłości. We współczesnych naukach społecznych i humanistycznych stał się palimpsest często eksploatowaną metaforą, pozwalającą zobrazować wielowarstwowość i wieloznaczność języka, sztuki, kultury, historii czy pamięci. W ujęciu strukturalno-semiotycznym jest to metafora szczególnie nośna, bowiem zawierają się $\mathrm{w}$ niej również pojęcia, które określają specyfikę przedmiotów badania oraz badawczych procedur (tekst, lektura, czytanie i pisanie jako metafory zarówno twórczości, jak i jej analizy, także: znak, znaczenie, interpretacja). W świetle powyżej zanotowanych skojarzeń zrozumiałe jest, że również w naukowej, eseistycznej i literackiej refleksji nad miastem palimpsest bardzo często był wyrazistym jego obrazem, niezwykle trafnie bowiem skupiał w sobie konstytutywne cechy miasta ${ }^{1}$, a ponadto, co podkreślam jako pierwszą tezę tekstu, palimpsest stawał się także metodą badania miasta, swoistym kluczem interpretacyjnym otwierającym pierwsze drzwi do jego rozumienia.

Miejski palimpsest w interpretacji semiotycznej ukrywa zatem pod zewnętrzną manifestacją czy reprezentacją (poziom signifiant) jakąś warstwę wewnętrzną, spodnią, należącą do przeszłości, często zapomnianą (poziom signifié). Na podobnym schemacie oparta jest większość prywatnych lub zbiorowych historii miast, także filmowych i literackich ${ }^{2}$ : od jakiegoś widocznego znaku (drobnego detalu, napisu, mieszkania, kamienicy, ulicy, dzielnicy) narracja prowadzi zwykle do jego początków lub do

$1 *$ Pierwodruk ukazał się w języku angielskim jako City-Palimpsest. A Semiotic Interpretation of Chernivtsi w książce pod red. Ewy Rewers, zatytułowanej: The Rise of City Cultures in the Central Europe, Warszawa 2015, s. 121-140. W obecnej wersji tekst został poddany koniecznej rewizji, jednakże z uwagi na konteksty jego powstawania (badania empiryczne, 605. rocznica miasta, konkretne wydarzenia i artefakty) niemożliwe było wprowadzenie wszystkich aktualizacji. Por. A. Huyssen, Present Past. Urban Palimpsest and the Politics of Memory, Stanford University Press, Stanford 2003.

2 Por. H. Wirth-Nesher, City Codes. Reading the Modern Urban Novel, Cambridge 1996; A. Bagłajewski, Miasto - palimpsest, w: Miejsce rzeczywiste - miejsce wyobrażone. Studia nad kategoria miejsca $w$ przestrzeni kultury, red. M. Kitowska-Łysiak, E. Wolicka, Lublin 1999; J. Gutorow, Palimpsest czy szyfr? O przedstawieniach (po)nowoczesnego miasta amerykańskiego, w: Miasto. Przestrzeń, topos, człowiek, red. A. Gleń, J. Gutorow, I. Jokiel, Opole 2005. 
początkowej relacji z nim narratora. Czytanie palimpsestu jest historią opowiadaną wstecz. Dodatkową wartością takiej interpretacji jest wskazanie na krzyżujące się kategorie przestrzeni (materialny znak) i czasu (powrót do przeszłości). W niemal namacalny sposób diachronia łączy się z synchronią ${ }^{3}$ Symbolicznym zwieńczeniem tej kumulacji skojarzeń może być znana opowieść o mieście o nazwie... Palimpsest ${ }^{4}$.

O ile jednak właściwie każde miasto można nazwać palimpsestem, chociażby w związku z jego historycznym rozwojem w najbardziej uchwytnej, materialnej warstwie (miasto zawsze powstaje przez dodawanie ${ }^{5}$ ), o tyle jedynie niektóre z nich są dla semiotycznej analizy wręcz modelowe. Tak można potraktować większość miast byłego bloku wschodniego w Europie (na przykład w Polsce) czy Rosji (i byłym Związku Socjalistycznych Republik Radzieckich), gdzie przesuwanie granic państwowych oraz kolejne zmiany polityczne prowadziły do - rozumianego już całkiem wprost - „przepisywania” miejskiego „tekstu”. Najbardziej wyczerpującą semiotyczną analizę miasta (w tym miasta-palimpsestu) zaprezentował Władimir Toporow (przedstawiciel szkoły tartusko-moskiewskiej) w swych tekstach poświęconych Petersburgowi ${ }^{6}$ - miastu w założeniu jego twórcy „idealnemu”, zbudowanemu od podstaw, zmieniającemu swe imię wraz ze zmieniającą się władzą. Tak samo modelowo mogłyby być potraktowane ukraińskie Czerniowce, wystarczy przywołać wspomnienie Jurija Andruchowycza: „Odziedziczyliśmy Czerniowce z ich niepowtarzalną, odrapaną, magiczną i oplecioną winoroślą aurą, z rozmaitą powojenną (inną) ludnością, z zarośniętymi podwórzami, w których innojęzyczne (rumuńskie?, niemieckie?) napisy przedzierały się przez mury nieczytelnymi złowieszczymi znakami"7.

Empiryczne badania przeprowadzone w mieście, uczestnictwo w niektórych wydarzeniach kulturalnych, kontakt z mieszkańcami oraz kwerenda biblioteczna pozwalająjednak stwierdzić coś więcej: otóż Czerniowce, coraz bardziej świadome swej palimpsestowości, w zaplanowany sposób piszą kolejną warstwę miejskiego tekstu. Drugą ważną tezą niniejszego artykułu jest zatem próba zaprezentowania Czerniowiec jako palimpsestu samoświadomego i żywego, nie tyle czytanego „wstecz”, ile permanentnie pisanego czy przepisywanego - zarówno przez mieszkańców, jak i turystów oraz badaczy. Jak stwierdziła Ewa Rewers, „palimpsest należy bowiem do wszystkich, którzy zostawili na nim swój ślad, lecz nikt nie ogarnia całości zapisu, ponieważ zapisuje tylko jedną jego warstwę, a kolejne stadia inicjuje raczej

\footnotetext{
${ }^{3}$ Takie ujęcie pozwala na poszerzenie i zdynamizowanie definicji miejskiego palimpsestu, w ramach której badacze odwołują się zwykle do koniecznej, oczywistej temporalności i historycznych warstw miasta, ale jednocześnie wskazywać mogą na „miejski krajobraz pamięci jako pole konfliktu”; por. E. Rybicka, Pamięć i miasto. Palimpsest vs. pole walki, „Teksty Drugie” 2011, nr 5, s. 210.

${ }^{4}$ Por. C.M. Valente, Palimpsest, przeł. W. Szypuła, Warszawa 2010.

${ }^{5}$ Por. T. Sławek, Miasto. Próba zrozumienia, w: Miasto w sztuce - sztuka miasta, red. E. Rewers, Kraków 2010, s. 44.

${ }^{6}$ Por. W. Toporow, Peterburgskij tekst russkoj literatury. Izbrannye trudy, Iskusstwo-SPb, Sankt -Peterburg 2003.

7 J. Andruchowycz, Leksykon miast intymnych. Swobodny podręcznik do geopoetyki i kosmopolityki, przeł. K. Kotyńska, Wołowiec 2014, s. 77.
} 


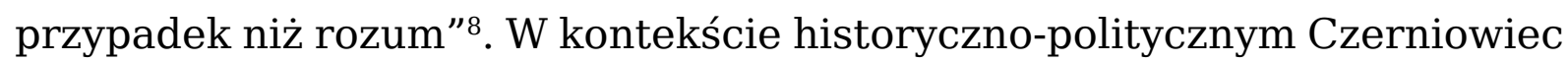
relacja przypadku i rozumu układa się raczej jako rodzaj konfliktu: z jednej strony, rozum symbolizuje kolejne celowe działania polityczne (będzie to sfera przemocy i władzy, najczęściej systematycznie i odgórnie wdrażanej), ze strony drugiej natomiast - pojawia się przypadek jako pole działania na przekór kolejnej władzy, obszar tożsamości narodowej, religijnej, językowej (zwykle wzajemnie sprzężonych), sfera tradycyjnych i ponowoczesnych miejskich kultur oraz prywatnych rozstrzygnięć, a także szereg drobnych lub bardziej spektakularnych symbolicznych gestów - ingerujących w tkankę miasta i pozostawiających w niej interpretacyjny ślad.

\section{Czerniowce - palimpsest}

W pewnym sensie Czerniowce zawsze miały palimpsestowy charakter i zawsze prowokowały mieszkańców oraz przyjezdnych do takich właśnie interpretacji. To znaczy, że wielowarstwowość miasta nie jest tylko sprawą interpretacyjnych czy perswazyjnych umiejętności badacza, ale że - ze względu na szereg czynników - niejako „naturalnie” jest ono palimpsestowe. Wskazuje na to chociażby zagmatwana historia. Trudno szukać na mapie świata tak modelowego przykładu działania zewnętrznych (politycznych i kulturowych) czynników na miasto i trudno się też dziwić tak wielkiej nim fascynacji turystów, badaczy miast oraz znawców i miłośników niemieckojęzycznej literatury Bukowiny (na przykład poezji urodzonego w Czerniowcach Paula Celana). Jakże często zresztą wszystkie z wymienionych tu cech występują w połączeniu, co dodatkowo pozwala na dostrzeganie wielu niuansów zatartego palimpsestu.

Pierwsza wzmianka na temat Czerniowiec pochodzi z roku 1408. Jest to czas przynależności Bukowiny do Mołdawii, potem z kolei - od XVI wieku - znalazła się ona pod panowaniem Turcji. Od 1775 roku Bukowina wraz z Czerniowcami należała do Monarchii Austro-Węgierskiej, by w roku 1849 stać się stolicą niezależnego od Galicji Księstwa Bukowiny - i to był też czas największego rozkwitu miasta, zarówno w znaczeniu urbanistycznym, architektonicznym i cywilizacyjnym, jak i kulturowym. W związku z pogranicznym charakterem miasta, jego przeszłością i statusem swoistego centrum wschodniej Europy dla napływowej ludności, Czerniowce w połowie XIX wieku, jak pisał Helmut Böttiger, były „zamieszkiwane przez same mniejszości” ${ }^{9}$. Na przełomie XIX i XX wieku każda większa grupa etniczna miała tu swój „narodowy” dom, a duchowi przewodnicy najważniejszych wyznań właściwie ze sobą współpracowali. Z różnego rodzaju wspomnień (a w związku z fenomenalnym rozkwitem inteligencji oraz w związku z licznymi odwiedzinami atrakcyjnego miasta na krańcach Europy wspomnień z tamtego czasu zachowało się stosunkowo wiele) przebija przekonanie, że przedwojenne Czerniowce były miastem idealnym, w którym na równych prawach koegzystowały rozmaite miejskie kultury. Z perspektywy czasu

${ }^{8}$ E. Rewers, Post-polis. Wstęp do filozofii ponowoczesnego miasta, Kraków 2005, s. 303.

${ }^{9}$ H. Böttiger, Paul Celan. Miasta i miejsca, przeł. J. Ekier, Olsztyn 2002, s. 17. 
widać też pewien paradoks: w znaczeniu geograficznym było to miasto prowincjonalne, wysunięte daleko na wschód Europy, ale jednocześnie znajdujące się w centrum: słynne stały się już opisy wielości księgarń, kawiarń i kościołów w Czerniowcach, relacje na temat prasy abonowanej z Pragi, Wiednia czy Lwowa i dostępnej codziennie w licznych kawiarniach, ale także na temat gazet wydawanych na miejscu, w których każde drobne zdarzenie zamieniało się w literaturę ${ }^{10}$. Kultura stała się swego rodzaju płaszczem zdolnym pomieścić w sobie wiele warstw palimpsestu. Norman Davies, jak zresztą wielu badaczy i pisarzy, którzy swą uwagę poświęcili stolicy „najdalej wysuniętego przyczółka posiadłości Habsburgów”, użył tu charakterystycznego języka, naznaczonego palimpsestową metaforyką: „[stolica owa] była ośrodkiem życia wielojęzycznej, wielowyznaniowej, hierarchicznej społeczności, na którą niemiecka i cesarska kultura Mitteleuropy nałożyła się jak arkusz przezroczystej folii, przykrywający warstwy bogatej kultury żydowskiej, rumuńskiej, polskiej i ruskiej"11.

Lata 1918-1940 to okres rumuński Bukowiny i Czerniowiec (paradoksalnie - w okresie międzywojennym powstała znaczną część bukowińskiej literatury niemieckojęzycznej). 20 czerwca 1940 wkroczyła Armia Czerwona (na rok), w lipcu 1941 z kolei - wojska rumuńskie pod dowództwem niemieckich nazistów. W 1944 znów i na długo tym razem zapanowała władza sowiecka, by w 1991 roku - wraz z uzyskaniem niepodległości przez Ukrainę - stały się Czerniowce (z około 260 tysiącami mieszkańców) stolicą najmniejszego obwodu Ukrainy. W roku 2008 miasto hucznie obchodziło swe 600-lecie, w 2013 - kolejną rocznicę 605 lat istnienia. To już etap bardzo świadomych swej skomplikowanej historii działań, co w tkance miasta (remont cudem ocalałej z historycznej zawieruchy starówki) i materiałach promocyjnych uzewnętrznia się chociażby graficznym wykorzystaniem najstarszego zapisu nazwy miasta.

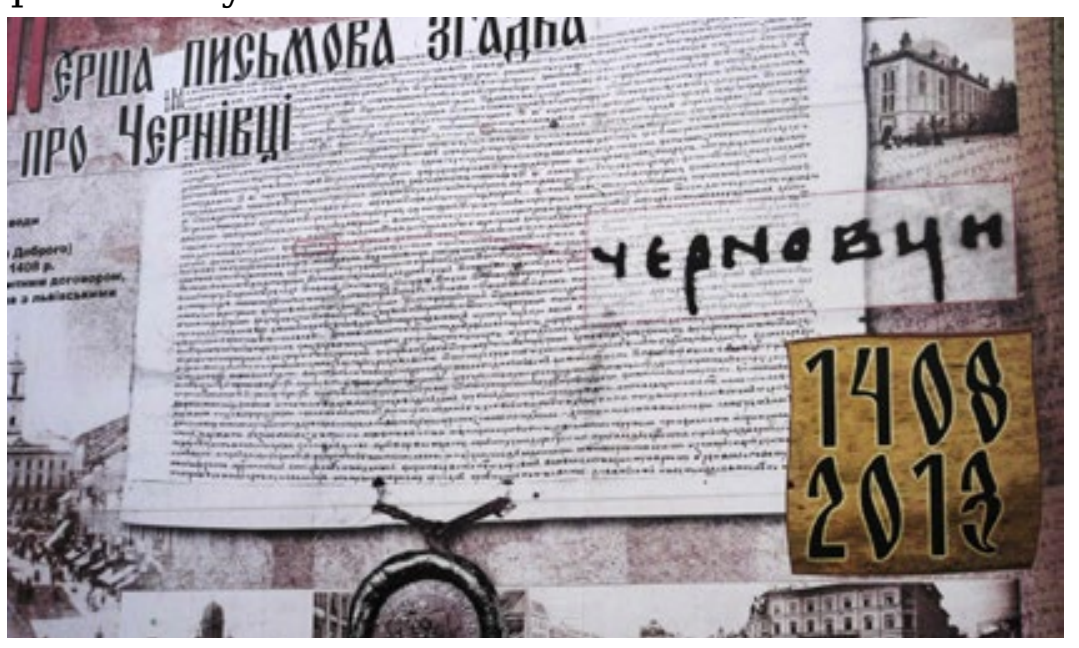

1. Fragment monumentalnej instalacji umieszczonej na Placu Centralnym z okazji 605. rocznicy pierwszej pisemnej wzmianki na temat Czerniowiec (fot. R. Koschany)

${ }^{10}$ Por. M. Pollack, Po Galicji. O chasydach, Hucułach, Polakach i Rusinach. Imaginacyjna podróż po Galicji Wschodniej i Bukowinie, czyli Wyprawa w świat, którego nie ma, przeł. A. Kopacki, Wołowiec 2007, s. 166-171.

${ }^{11}$ N. Davies, Europa. Rozprawa historyka z historia, przeł. E. Tabakowska, Kraków 1999, s. 1074. 
Wobec pobieżnie nakreślonej tu historii miasta, odwołującej się do jakiegoś mitycznego czasu harmonii oraz jej systematycznej i okrutnej degradacji, palimpsestowość dobitnie wybrzmiewa w kontekście zapisów indywidualnych historii - osób, urodzonych na przełomie XIX i XX wieku, które doczekały ostatnich przemian politycznych i wolnej Ukrainy. Pamiętały więc jeszcze wielokulturowy tygiel Czerniowiec, I wojnę światową, kiedy miasto przez dłuższy czas znajdowało się na linii frontu, władzę rumuńską, kolejno wojska czerwonoarmijskie i nazistowskie, władzę radziecką, wreszcie ukraińską. Można powiedzieć, że to (na wzór ludzi-opowieści Tzvetana Todorova) ludzie-palimpsesty. To już nie tylko przykład „dwoistego ducha”, jaki na przełomie XIX/XX charakteryzował zasymilowanych Żydów piszących po niemiecku ${ }^{12}$, ale po wielokroć zapisane biografie, przez całe życie poddawane kolejnym tożsamościowym próbom, tak jakby na sylwetkach postaci - wraz z ich całym biograficznym doświadczeniem - „wyświetlała” się historia miasta. O jednej z nich pisał Böttiger: „Zmieniała obywatelstwo z ck austriackiego kolejno na rumuńskie, radzieckie, a obecnie ukraińskie, mimo że mieszkała wciąż $\mathrm{w}$ tym samym miejscu i nigdy nie chciała się ruszać z Czerniowiec"13.

Szczególnie wyraźnie naszkicowane wyżej przemiany odzwierciedlają się w historii języka Czerniowiec (w semiotyce miasta jest to zawsze ważny przedmiot analiz). Zacząć można od owego punktu miejskiej doskonałości, czyli przełomu XIX i XX wieku. Odnotowane wówczas lub później, ale odnoszące się do tamtego czasu, liczne peryfrazy miasta składają się na dodatkowy (i uniwersalizujący) wymiar myślenia o nim - symbolicznego, semiotycznego, palimpsestowego wreszcie. Oto kilka z nich: „mała Jerozolima nad Prutem”14, „Babilon Europy Środkowej” oraz „Babilon wschodniego żydostwa”, „tajemna stolica literatury niemieckiej”, „Europa w miniaturze”, „mały Wiedeń” oraz - jak Czerniowce nazwał Zbigniew Herbert - „ostatnia Aleksandria Europy” i „cytadela europejskości”. Nawet sieć powiązań poetyckich lat 30. XX wieku mogłaby wskazywać na inny jeszcze aspekt palimpsestowego charakteru miasta; jak pisał Böttiger, Czerniowce literackie stanowiły „jedną sieć metafor i jeden świat obrazów”15.

Niestety, przyspieszone przemiany polityczne XX wieku pociągnęły za sobą przyspieszone zmiany językowe. Żywa wielogłosowość przedwojennych Czerniowiec w jednej chwili zastąpiona została oficjalnym językiem rumuńskim, potem rosyjskim, a zatem - oprócz zmiany języka - nastąpiła też zmiana alfabetu (z łacińskiego na cyrylicę). Następowały też kolejne przemianowania nazw ulic czy placów, pomniki zgodne z aktualną władzą

${ }^{12} \mathrm{Na}$ Waltera Benjamina powoływał się tu P. Rychło, Szibbolet. Poszukiwania tożsamości żydowskiej w niemieckojęzycznej poezji Bukowiny, przeł. A. Chłopik, P. Jarosz, Kraków - Budapeszt 2012, s. 11.

${ }^{13}$ H. Böttiger, op. cit., s. 35.

14 Pollack pisze w tym kontekście o tendencjach antysemickich - określenie to używane było pogardliwie przez niemieckich volkistów; por. M. Pollack, op. cit., s. 161.

${ }^{15}$ H. Böttiger, op. cit., s. 23. 
zastępowały poprzednie ${ }^{16}$. W tym miejscu XX-wieczne Czerniowce przypominają wiele miast byłego ZSRR, są więc jednym $\mathrm{z}$ „przemianowanych miast”, jak o Petersburgu napisał Josif Brodski ${ }^{17}$. Przypominają, a jednocześnie są wyjątkowe - ze względu na permanentny i związany z polityczną przemocą proces „przechwytywania”.

W tym kontekście można już zapowiedzieć wątek z następnej części rozważań. Otóż dzisiejsza skomplikowana sytuacja na Ukrainie, związana z dążeniami - z jednej strony - proeuropejskimi, z drugiej zaś - prorosyjskimi, sprawia, że Czerniowce jako miasto-palimpsest są księgą wiecznie otwartą, na kartkach której dochodzi do ciągłego pomieszania języków i alfabetów (cyrylica miesza się tym razem z oryginalnymi nazwami światowych sieci handlowych). Krwawe wydarzenia w Kijowie, nazwane zbiorczo Euromajdanem, w których wzięli udział również mieszkańcy Czerniowiec, doprowadziły do kolejnych symbolicznych zmian. We współczesnym kontekście geopolitycznym, w tej części Europy raczej od dawna ustabilizowanym, nie zdarza się to często, ale wydarzenia na Ukrainie 2014 roku zbyt silnie odcisnęły się w świadomości mieszkańców miast, by nie zareagowali oni na to w sposób symboliczny: kilkoma zmianami nazw ulic ${ }^{18}$. I tak dawną ulicę Wasilija Czapajewa przemianowano na Oleksandra Szczerbaniuka (zabitego przez snajpera na Majdanie 20 lutego 2014, czerniowieckiego działacza społecznego i politycznego, Żyda oraz członka organizacji chrześcijańskiej, opozycjonisty za czasów prezydentury Janukowycza); nazwę ulicy Czerwonoarmijskiej zmieniono na Bohaterów Majdanu; Iwana Stasiuka - na Niebiańskiej Sotni.

Gdyby na mapie Czerniowiec oraz w ich historii szukać jakiegoś punktu, w którym skupiałyby się zanotowane wyżej procesy, z pewnością byłaby to wielka chóralna synagoga Templ ${ }^{19}$. Wniesiona została w latach 70. XIX wieku przez czerniowieckich reformowanych Żydów (zaprojektował ją w mauretańskim stylu Julian Zachariewicz). W 1941 zdewastowana w ramach faszystowskich działań, w 1959 - zgodnie z ukazem Chruszczowa - pozbawiona została mauretańskich zdobień i kopuły i przemianowana na kinoteatr „Żowten” [październik], jeden z najnowocześniejszych wówczas przybytków kultury tego typu, prężnie działający i przynoszące niezłe zyski. Mieszkańcy nazwali to miejsce kinogogą - i tak już zostało. Nieoficjalny

${ }^{16}$ Por. E. Polak, Where is Lenin? Local political discourse in Chernivtsi, w: Multi-cultural remembrance and the permanence of traces. Chernivtsi in the Bukovina, http://www.geschichtswerkstatt-europa.org/media/projekte/MulticulturalremembranceandthepermanenceoftracesChernivtsiintheBukovina.pdf [dostęp: 30.04.2014].

17 Por. J. Brodski, Dyptyk petersburski, czyli przewodnik po przemianowanym mieście, przeł. P. Hertz, Fundacja Zeszytów Literackich, Warszawa 2003.

18 P. Andrusieczko, Chwała bohaterom, śmierć okupantom, „Gazeta Wyborcza” 11.04.2014, s. 13. Specjalne podziękowania za dokładniejsze informacje na ten tematzechce przyjąć Oleksandr Bojczenko z Czerniowiec.

19 Por. J. Jabłońska, Cinemagogue in Chernivtsi, w: Multi-cultural remembrance and the permanence of traces..., op. cit. Kinogoga nie jest, oczywiście, jedyną przemianowaną synagogą w Czerniowcach; większość z ocalałych z powojennej pożogi spotykał ten sam los w całej komunistycznej części Europy. Skalę takiego przemianowania w Polsce pokazuje książka Wojciecha Wilczyka (Niewinne oko nie istnieje. There's no such thing as an innocent eye, Łodź - Kraków 2009). 
neologizm odzwierciedla palimpsestowy i zdesakralizowany charakter przestrzeni (znów można powiedzieć: jej „dwoistego ducha”, ale tym razem sformułowanie to użyte jest w dyskursie okrutnej ironii historycznej), którym - jak się wydaje - próbowano obłaskawić drastyczną w wymowie sytuację zniszczenia i przemianowania. Dziś kinogoga nosi nazwę „Czerniwci”, oblepiona jest współczesnymi plakatami filmowymi (z bieżącego repertuaru) oraz licznymi straganami. Fascynuje swą historią, a jednocześnie przygnębia - zwłaszcza w kontekście zadbanego placu teatralnego, odnowionej starówki i tętniących życiem kawiarni nawiązujących do austrowięgierskich tradycji na głównym deptaku miasta. Z rozmów z mieszkańcami przebija nie tyle obojętność w tej kwestii, ile przyzwyczajenie. Z kilkudziesięciu synagog sprzed wieku czynna została jedna (niewielka synagoga Beniamina), reszta została zniszczona albo - znów - przemianowana. Uważny przechodzień, nawet pozbawiony odpowiedniej dokumentacji, część z nich będzie mógł rozpoznać po nielicznych śladach i detalach architektonicznych - prześwitującego spod spodu „tekstu”.

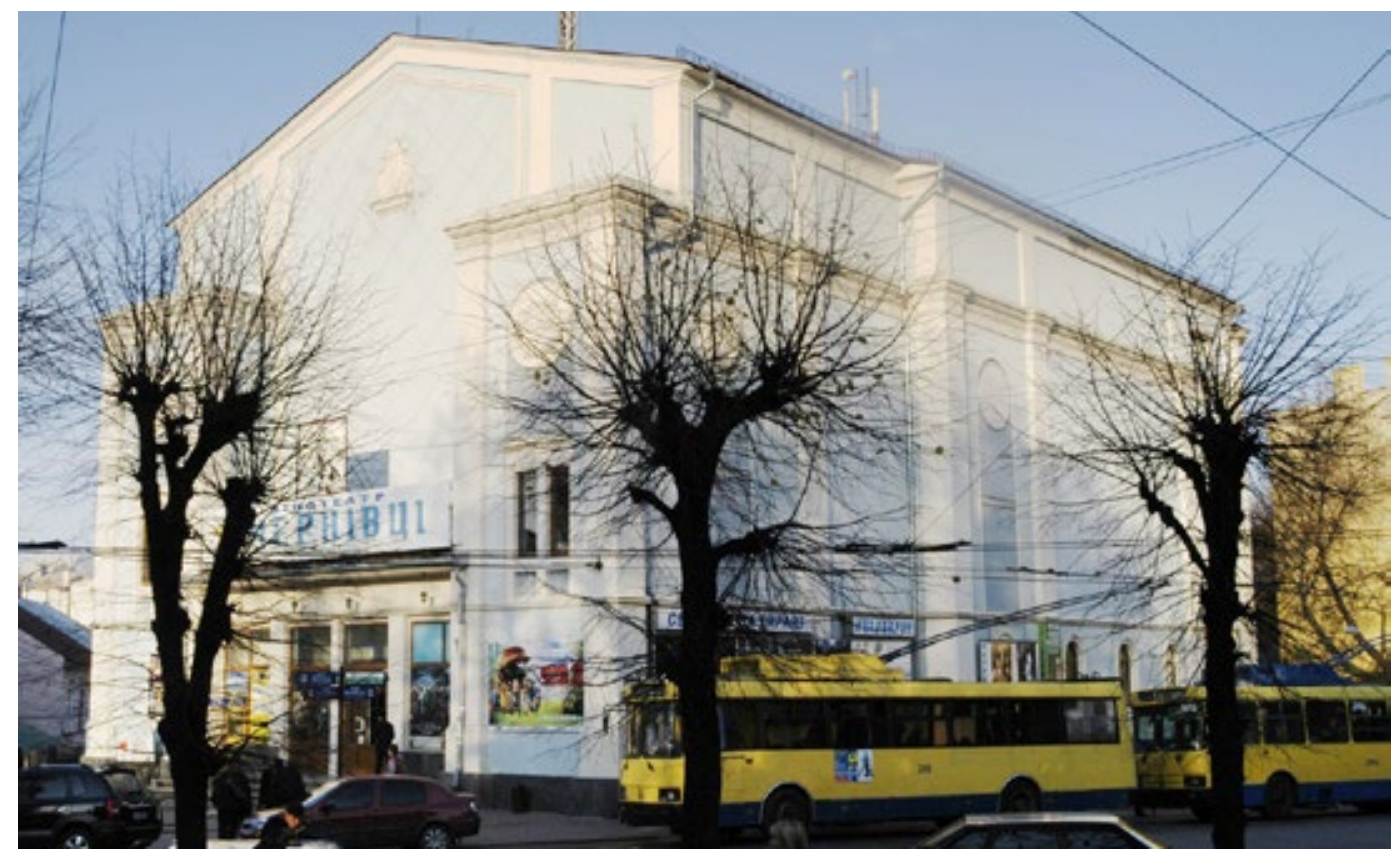

2. Kino (kinogoga) „Chernivtsi” (fot. R. Koschany)

\section{Bruk i rama}

O ile wcześniejsze - po okresie bezkonfliktowej wielokulturowości, wieloreligijności i wielojęzyczności - warstwy czerniowieckiego palimpsestu można interpretować jako „zapisy” naznaczone przemocą, zależne od historycznych i politycznych kontekstów, o tyle dziś próbuje się wykorzystać doświadczenia historii w celu pozytywnego i twórczego „przepisania" starych warstw. Analizowane z tej perspektywy współczesne działania mieszkańców i władz Czerniowiec przekonują, że jest to ciągła i w pełni świadoma przeszłości praca na istniejącym już palimpseście: „present 
past”, jak brzmi tytuł przywoływanej książki Huyssena. Tylko uważne czytanie dziedziczonego tekstu pozwala na pisanie nowego, jednakże o ile próby analizy czerniowieckiego dziedzictwa, jako efektu działania nazistów i sowietów, zatrzymują się często na dyskursie negatywnym (brak, pustka, zagłada, dewastacja, cisza, melancholia), o tyle dziś opis ten - wybiegający w przyszłość i związany ze strategią marketingową miasta - jest „zapełniony" i eliptyczny: konsekwentnie odwołuje się do wybranego, mitycznego okresu rozwoju miasta i jego kultury.

Historia Czerniowiec naznaczona jest kolejnymi przemianowaniami, zamazaniami i przekształceniami - co w szczególnie dojmujący sposób widoczne jest w materialnej tkance miasta (by odwołać się do modelowego przykładu kinogogi). Czasem zmiany te miały o wiele mniej „spektakularny" charakter, ale jakże symboliczny: na przykład odpiłowane po wojnie ramiona gwiazd Dawida na balustradach w Domu Żydowskim, kiedy stał się on miejskim domem kultury. Właśnie w tak symboliczny sposób próbuje się tę małą historię odzyskać, ponownie zapełniać wymownymi znakami, co miało miejsce przede wszystkim w okołorocznicowym czasie. Spodziewać się jednak można stałej już odtąd próby wykorzystania symbolicznej historii miasta, szczególnie odwołań do wizualnych elementów jego tożsamości. Dzisiejsze, twórcze pisanie palimpsestu i ożywianie w ten sposób miasta oraz aktywizowanie jego mieszkańców i turystów można pokazać na dwóch różnych przykładach, w których - co szczególnie warte podkreślenia - widoczna jest intencja zaangażowania miejskich podmiotów, sprowokowania ich do refleksyjnego potraktowania swej roli: zamieszkiwania, zwiedzania lub badania miasta.

Spośród stałych, ale symbolicznych ingerencji w materialną tkankę miasta (na przykład „rocznicowe” ławki z użyciem napisu „Чернівці”), za najbardziej znaczącą i efektowną zarazem można uznać renowację nawierzchni głównego, reprezentacyjnego deptaku - ulicy Olgi Kobylańskiej. W koncepcie tym, po pierwsze, bardzo wyraźnie widać, jak nazwa miasta sklejona jest z jej zapisem, graficzną reprezentacją, która korzysta z repertuaru danego systemu językowego. W każdym z okresów politycznych zawłaszczeń utrwalała się właśnie taka binarna struktura nazwy i zapisu. Na czerniowieckim deptaku, po drugie, otrzymujemy historię tych przemian: zwielokrotnione, zgodne z historycznymi wersjami urzędowe nazwy miasta, nazwy używane przez narodowe i językowe większości oraz nazwy zapisane $\mathrm{w}$ funkcjonujących w Czerniowcach alfabetach: łacińskim, cyrylickim i hebrajskim. Wzdłuż ulicy, po jej dwóch stronach, w funkcji oddzielającej część "chodnika” od „jezdni”, pojawiają się podłużne, ozdobne, odróżniające się od reszty kształtem i kolorem płyty z napisami: CHERNIVTSI, Черновцы, CZERNIOWCE, CERNĂUŢI, ציוואנָרעשט, TSCHERNIWZI. Sam pomysł nawiązuje w jakiś sposób do poholokaustowych stolpersteine („kamienie pamięci” lub, w polskiej próbie znalezienia odpowiednika, „potykacze”) - wyróżnionych z chodnika kostek brukowych, na których umieszczony został znak 
lub napis, najczęściej upamiętniający osobę związaną z danym miejscem, będącą ofiarą nazizmu. Czerniowieckie „kamienie pamięci” odnoszą się tymczasem, z jednej strony, do wszystkich ludzi (mieszkających, powracających i "tylko” zainteresowanych), z drugiej zaś - „opowiadają” całą (od początku do dziś) historię miasta. Metafora palimpsestu została tu udosłowniona, a sam palimpsest - wprawiony w ruch. Mieszkańcy i turyści przechadzają się bezpośrednio po - symbolicznych wprawdzie - znakach przeszłości, tak jakby deptak zamieniał się w ogromną mapę lub oś czasu, po której poruszają się kolejne grupy przechodniów, być może w przyszłości - kolejne ich pokolenia. Dla niewtajemniczonych brukowe kostki z napisami są prowokacją do lektury: trzeba się pochylić, by odczytać napis, trzeba rozpoznać pomysł wielojęzycznego zapisu nazwy „Czerniowce”, wreszcie trzeba kawałek drogi przejść, by odgadnąć kombinację napisów. Wędrówka i lektura turysty niekoniecznie zgodna jest z chronologią zdarzeń, jest ona raczej przypadkowa, tak jak na drodze poznania (czytania palimpsestu) ukazują się rozmaite warstwy przeszłości.

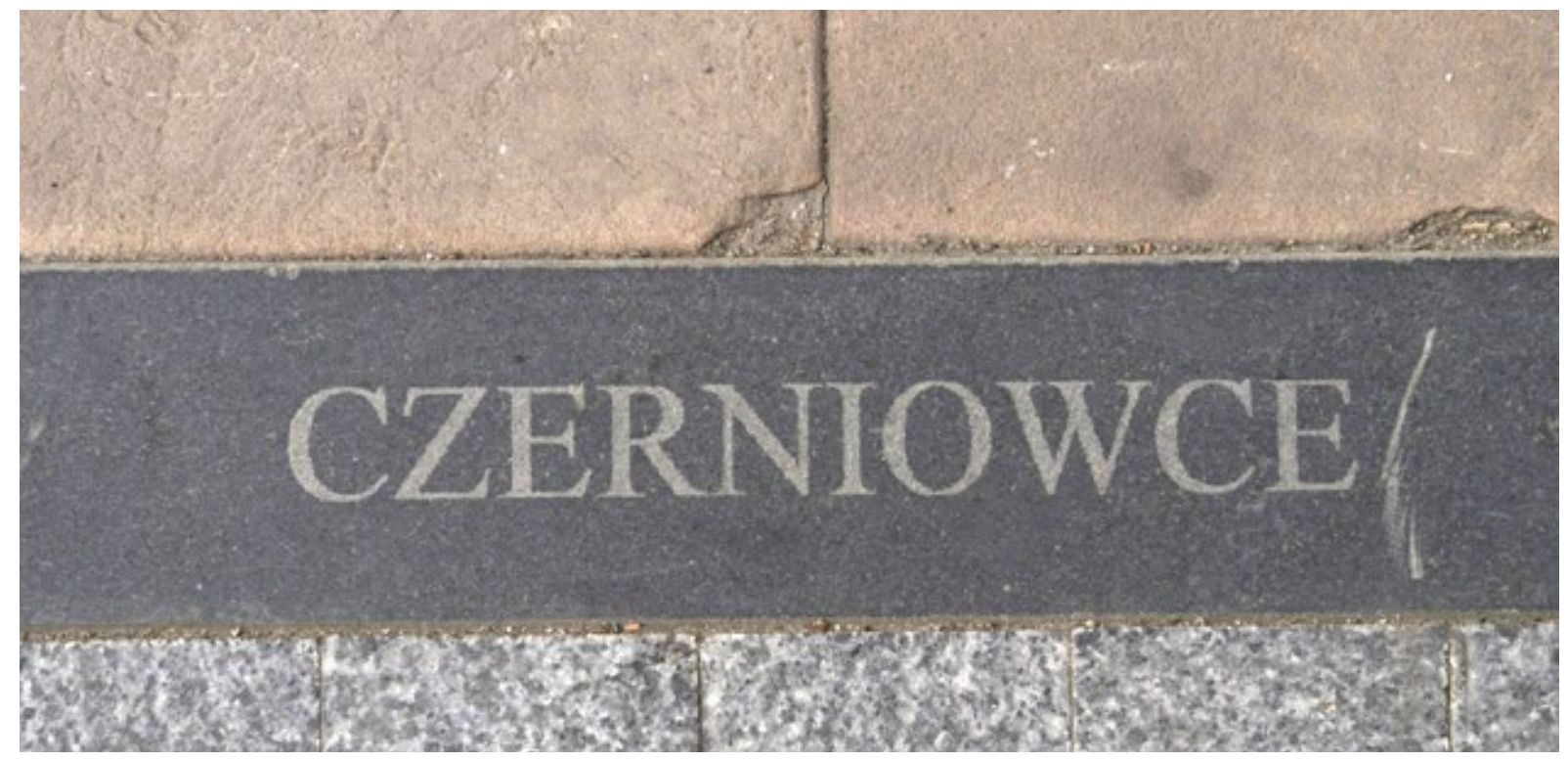

3. Jedna z płyt brukowych na ul. O. Kobylańskiej z polskim napisem „Czerniowce” (fot. R. Koschany)

Innym przykładem działania reinterpretującego miasto, ciekawą próbą odnowienia relacji pomiędzy przeszłością a teraźniejszością w przestrzeni miejskiej, jest umieszczenie w centrum ogromnej pustej ramy - najpierw na Placu Centralnym, potem na Placu Teatralnym (tak było w październiku 2013). Rama pojawiła się z okazji rocznicy miasta i przez większość turystów odbierana była przede wszystkim jako sympatyczny, kontrastujący z dostojnym kompleksem zabytków „gadżet” czy „mebel miejski”. Służyła głównie do niekonwencjonalnego, jak owa większość sądziła, fotografowania się na tle miasta. Miejscowa młodzież chętnie wykorzystywała ramę jako miejsce spotkań, ale dotyczy to również turystów przebywających w mieście dłużej niż jeden dzień. 
Interpretacja socjosemiotyczna podpowiada, że trafna transakcentacja przestrzeni przyczynić się może do zmiany (mieszkańcy) lub kształtowania nowych nawyków (turyści) poruszania się po mieście. W ujęciu strukturalnym zaś i w próbie pokazania, jak w ogóle powstaje miejski palimpsest i jak można go „czytać”, czerniowiecka rama zyskuje dodatkowe jeszcze znaczenia. Zgodnie z ustaleniami Jurija Łotmana czy Borisa Uspienskiego ${ }^{20}$, rama (rozumiana metaforycznie, ale jako skojarzenia pojawiają się u badacza rama obrazu czy zarys sceny teatralnej) oddziela tekst artystyczny od jego zewnętrza, nie-tekstu. Zależnie od interpretacji samej ramy owe linie demarkacyjne przebiegają za każdym razem inaczej, choćby z tego względu, że raz może ona należeć do tekstu, a raz do zewnętrznej wobec niego rzeczywistości. Pytania, które prowokuje rama, dotyczą statusu wyróżnionego fragmentu, jego charakterystyki i sposobów lektury, które rama może przecież narzucać. W przypadku tekstu literackiego, przede wszystkim o fabularnym charakterze, rama będzie się też odnosić do układu zdarzeń, wraz z ich początkiem, środkiem i końcem. Dzieło sztuki ograniczone ramą staje się swoistym symbolem - zagęszczoną metaforą życia.

Tymczasem rama obrazu, także taka symboliczna rama przeniesiona w przestrzeń miejską, każe zramowane dzieło sztuki czytać w głąb - w naszym przypadku (i jest to główny „efekt” działania czerniowieckiej ramy) nie chodzi o trójwymiarowy charakter widzianej rzeczywistości, ale o nakładanie się kategorii przestrzeni i czasu. Patrzymy na przestrzeń i widzimy historię prześwitującą spod spodu, jakbyśmy byli widzami interpretującymi obraz: po lewej stronie „obrazu” Narodnyj Dim (Ukraiński Dom Ludowy), po prawej jedyny na placu budynek z międzywojennych czasów rumuńskich (Romanian National Palace), sprawiający wrażenie dziwnej architektonicznej plomby, dzisiaj już zabytkowej, i wreszcie w miejscu centralnym - na wprost umieszczony teatr: jako budynek pamiętający czasy habsburskie, a przed nim stojący kilkukrotnie przemianowany pomnik (pierwotnie był to Friedrich Schiller, potem - Mihai Eminescu, dziś - Olga Kobylańska). Istotny jest sam kontekst: rama umieszczona została na początku placu teatralnego i w ten sposób stała się „ramą” interpretacyjną: w nowoczesną ramę objęta została stara, reprezentacyjna część miasta. Rocznicowy status ramy niejako nakłada się na historyczny plac miasta; z kolei jej współczesny charakter, nawiązujący do estetyki graffiti, interpretacyjnie kontrastuje z klasycyzującą budowlą teatru (Czerniowiecki Ukraiński Teatr Muzyczno-Dramatyczny im. O. Kobylańskiej) i kompleksem pozostałych zabytków. W latach 90. XX wieku pisał Böttiger: „Stojąc na Placu Teatralnym, dawnym Elisabethplatz, w jednym okamgnieniu przenosimy się w przełom stuleci. (...) Czerniowce są dziś bardziej Czerniowcami niż Heidelberg Heidelbergiem”21. Dziś, patrząc z tego samego miejsca,

${ }^{20}$ Por. J. Łotman, Struktura tekstu artystycznego, przeł. A. Tanalska, Warszawa 1984; B. Uspienski, Strukturalna wspólnota rodzajów sztuki (na przykładzie malarstwa i literatury), w: Semiotyka kultury, red. E. Janus, M.R. Mayenowa, Warszawa 1977.

${ }^{21}$ H. Böttiger, op. cit., s. 28. 
ale „przez ramę”, odnowiony i zadbany Plac Teatralny być może jeszcze bardziej przypomina dawne Czerniowce, ale przede wszystkim staje się on „obramowanym” dziełem sztuki - miastem wymagającym interpretacji.

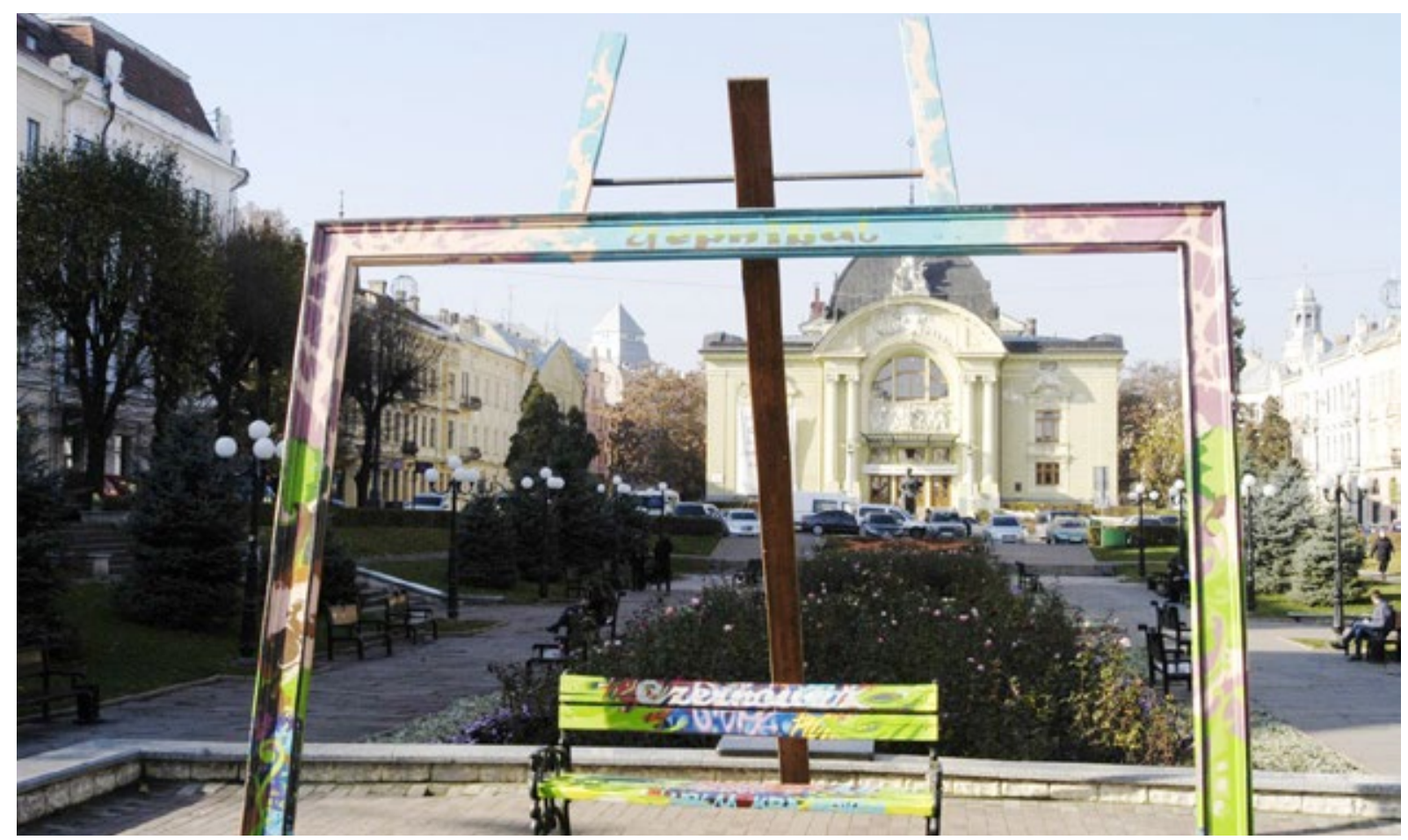

4. Plac Teatralny i jego współczesna rama (fot. R. Koschany)

\section{Czerniowce są książką}

Słynne sformułowanie Paula Celana na temat Bukowiny i samych Czerniowiec przełomu XIX i XX wieku („okolica, w której żyli ludzie i księ$\mathrm{gi}^{\prime 22}$ ) nie ma w sobie ani cienia przesady. Igor Pomerantsev, pisarz współczesny, który studiował w Czerniowcach, potem uprawiał turystykę literacką jeszcze przed jej instytucjonalizacją jako trendu na turystycznym rynku oraz jako tematu badawczego, a dziś współorganizuje tu festiwal literacki, potwierdza to silne skojarzenie: „For me, Chernivitsi is a city and Czernowitz is a book"23. Za nazwą idzie dziś nie tyle czy nie tylko konkretna wiedza historyczna, ale cały system symbolicznych konotacji.

W ostatniej części chciałbym spojrzeć na kwestię literatury jako trwałego, chociaż nie tak materialnego, jak w przypadkach notowanych powyżej, elementu budowy (albo odbudowy) marki miasta, uwzględnianego $\mathrm{w}$ strategiach promocyjnych, a także w rozwijającej się dzisiaj prężnie gałęzi turystyki kulturowej i literackiej.

W powołanym w 2010 roku do istnienia International Poetry Festival „Meridian Czernowitz” patronat Celana, jako jednego z najwybitniejszych

${ }^{22}$ P. Celan, Przemówienie z okazji przyjmowania Nagrody Literackiej Wolnego Hanzeatyckiego Miasta Bremy, przeł. F. Przybylak, w: Utwory wybrane, oprac. R. Krynicki, Kraków 1998, s. 315.

23 http://www.rferl.org/content/Interview_Seeing_Czernowitz_As_A_Retrospective Utopia/2148482. $\underline{\text { html }}$ [dostęp: 30.04.2014]. 
i najbardziej znanych poetów języka niemieckiego XX wieku, jest oczywisty. Jednakże mocną podstawą zarówno skojarzenia Czerniowiec z literaturą, jak i założeń festiwalu jest przecież cała pozostała plejada znakomitych pisarzy, a także - nieodłącznie - czasów, w których żyli. „There definitely is a retrospective utopia about the former Austro-Hungarian Empire", podkreślał Pomerantsev. Wśród świadomych mieszkańców, niezależnie od politycznych deklaracji czy działań władz, jest jakiś instynkt powrotu do centrum Europy - dzisiejszej, ale z wykorzystaniem dawnego kapitału symbolicznego. Jeden z ważnych celów festiwalu to zatem próba odzyskania historycznej i kulturowej pamięci. W materiałach prasowych, sprawozdaniach $\mathrm{z}$ kolejnych edycji festiwalu oraz w rozmowach z samymi jego organizatorami i uczestnikami wyraźnie podkreśla się cel zarówno kilkudniowego zdarzenia, jak i - właściwie całorocznych - działań okołofestiwalowych. Chodzi o ponowne włączenie Czerniowiec do szeregu ważnych miast europejskich oraz połączenie dwóch warstw palimpsestu: harmonijnej, wielokulturowej przeszłości i postulowanej - w nowej sytuacji geopolitycznej - „europejskości”. Imponujący jest więc udział w festiwalu międzynarodowych gości (prozaików i poetów z USA, Polski, Niemiec, Austrii, Szwajcarii, Francji Mołdawii, Rumunii, Izraela, Rosji, etc.), polityków (czerniowieckich, ale także z Kijowa), sponsorów wreszcie. Dodać również trzeba, że wyraźnie podkreśla się w tych działaniach tradycję kultury żydowskiej na Ukrainie, a tym samym - jest to idea skierowana przeciwko silnemu w dzisiejszej zachodniej Ukrainie antysemityzmowi (nacjonalizmowi także).

W założenia organizatorów festiwalu, w tej chwili już bardzo silnie obecnego w kulturalnym kalendarzu miasta, wpisane są długofalowe procesy i spodziewane trwałe skutki na tym polu. Nie mniej istotna jednak jest sfera konkretnych inicjatyw czy wydarzeń, zwłaszcza tych, które mają bezpośredni związek z miejską przestrzenią. Organizatorzy kolejnych edycji festiwalu i konkretnych przedsięwzięć uwzględniają zatem w programie literacką mapę Czerniowiec, przywracając ją pamięci mieszkańców i przedstawiając gościom (dotychczas, na poziomie miejskiej polityki oraz propozycji komercyjnych, ta sfera „turystyki literackiej” pozostaje raczej skromna i niewykorzystana ${ }^{24}$ ). Literackie spacery, a nawet trasy o europejskim zasięgu (np. „Poetry Tour” z 2013 roku: Kijów - Czerniowce - Lwów - Berlin - Brema), program rezydencyjny dla pisarzy z zagranicy (Internetional Residence for Poets and Translators „Meridian Czernowitz”), spotkania i imprezy w miejscach związanych z biografiami pisarzy lub ich upamiętniającymi, wreszcie powoływanie miejsc nowych (na przykład Centrum Paula Celana z siedzibą przy ul. O. Kobylańskiej) - wszystko to na powrót włącza literaturę w przestrzeń miejską. Program wzbogacany jest także o inicjatywy wychodzące poza ścisłe centrum miasta, jednakże na obecnym etapie nie można

${ }^{24}$ Dodatkowo, z tej skromnej oferty wydawniczej znaczna część publikowana jest ciągle wyłącznie w języku ukraińskim. Nawet dobre pomysły (na fot. nr 5 widnieje udana, palimpsestowa w zamyśle propozycja przewodnika turystycznego) nie przyczyniają się w tej sytuacji do wzmacniania turystycznego potencjału miasta. 
powiedzieć, by którejś z pozostałych dzielnic Czerniowiec w jakikolwiek sposób udało się skutecznie wyjść z etapu postsowieckiego.

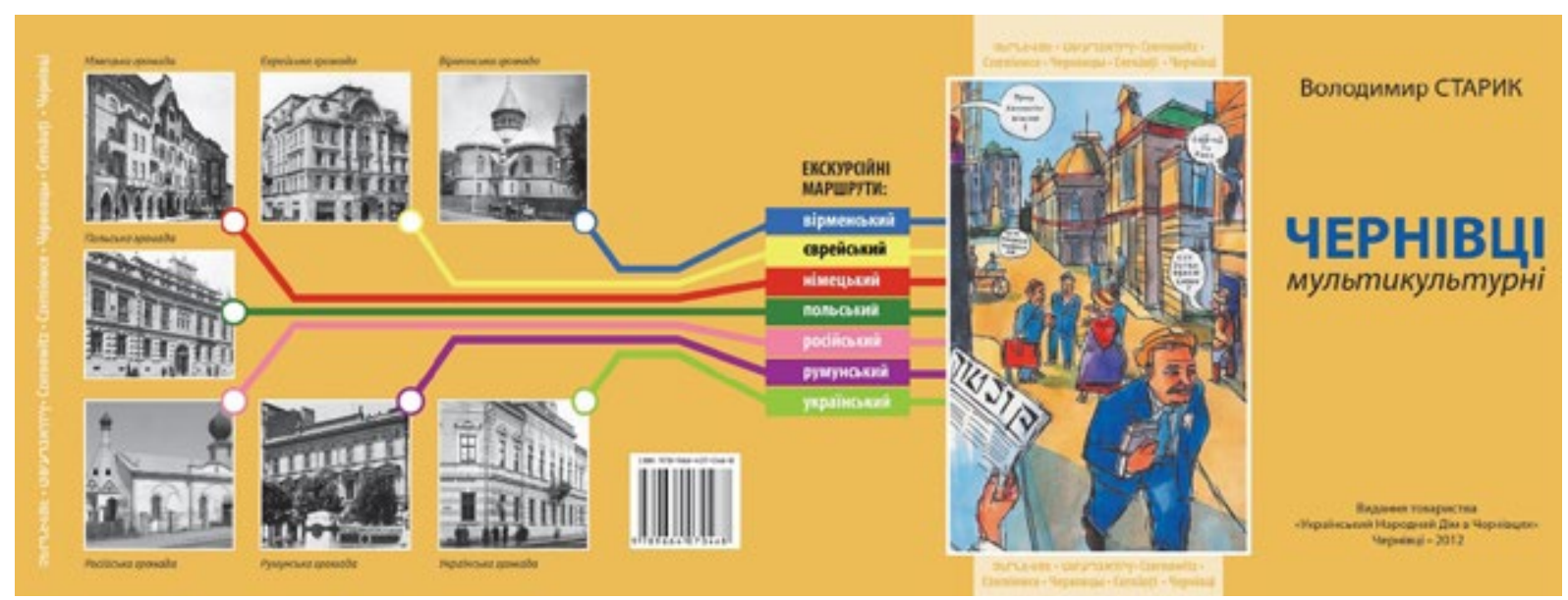

5. Rozłożona okładka jednego z przewodników po Czerniowcach (zgodnie z zaznaczonymi tu kolorami, na takiej samej matrycy mapy miasta osobno ułożone

są trasy wycieczek śladami kultur: ormiańskiej, żydowskiej, niemieckiej, pol-

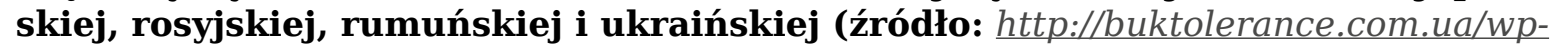
-content/uploads/2012/07/Chernivtsi-multykulturni.jpg).

W publiczną dyskusję dotyczącą relacji miasta i literatury, także we współczesnym kontekście, kiedy staje się ta relacja elementem marketingowych strategii, w istotny sposób włączyły się „Dni Brunona Schulza w Czerniowcach" (21-24.10.2013). Powodem bezpośrednim była rocznica (w 2012 roku obchodzono okrągłe daty narodzin i śmierci pisarza), wydanie z tej okazji - po stronie ukraińskiej - nowych lub pierwszych tłumaczeń jego twórczości ${ }^{25}$, a także zadzierzgnięcie współpracy pomiędzy Międzynarodowym Festiwalem Brunona Schulza w Drohobyczu (organizowanym co drugi rok od roku 2004) a festiwalem „Meridian Czernowitz”. Organizatorzy i uczestnicy zgodnie zaznaczali sieć podobieństw. Po pierwsze, podkreślano kwestię języka: obaj najbardziej znani na świecie spośród urodzonych na dzisiejszej Ukrainie pisarze tworzyli bądź po polsku (Schulz), bądź po niemiecku (Celan), co z perspektywy młodego czytelnika ukraińskiego nie jest oczywistością łatwą do przyjęcia (a wynika to albo z braków wiedzy historycznej, albo z politycznych przekonań) i stanowi ważny katalizator dla tożsamości współczesnych Ukraińców. Stąd też pytanie przewodnie dyskusji - po co nam Schulz?, w domyśle także: po co nam Celan? - w kontekście ukraińskim okazuje się ważne, ale nie do końca

${ }^{25}$ W procesie przyswajania twórczości Paula Celana (a także innych bukowińskich pisarzy niemieckojęzycznych) największe zasługi ma Petro Rychło, literaturoznawca z czerniowieckiego uniwersytetu, nie można tu jednak jeszcze mówić o zakończonym procesie translacji dzieła autora Fugi śmierci. Natomiast miejsce Schulza (piszącego znacznie wcześniej i szybciej też zaistniałego w panteonie literatury światowej) w kontekście języka ukraińskiego to dość zaskakująca opowieść: przez dłuższy czas dostępny był w niewielu i często niezbyt dobrych przekładach, nieobecny także w dyskursie akademickim, właściwie dopiero niedawno został całościowo przyswojony: w 2012 roku ukazało się nowe tłumaczenie (tym razem wszystkich już) tekstów literackich Schulza, autorstwa Jurija Andruchowycza (Cynamonowi kramnyci, przeł. J. Andruchowicz, Ababahalamaha, Kijów 2012), natomiast naukową debatę nad nim od dłuższego czasu skutecznie podejmuje Wiera Meniok (dyrektor Międzynarodowego Festiwalu Brunona Schulza w Drohobyczu oraz prezes Fundacji „Muzeum i Festiwal Brunona Schulza"). 
przepracowane. Językowa sytuacja Ukraińców względem tradycji literackiej, która miałaby pozwolić im na powrót do Europy, jest więc paradoksalna: „ich” pisarze pozwalają na reaktywację dawnej wielojęzyczności, ale jednocześnie w związku z tym, że nie pisali po ukraińsku, nie do końca są „ich”.

Po drugie, dwaj wielcy, światowej klasy pisarze stali się symbolami i ambasadorami ich miast rodzinnych, także - patronami międzynarodowych festiwali literackich. Przedmiotem porównania są tu więc dwa literackie miasta, a celem - próba ich interpretacji przez pryzmat legendy urodzonych tam twórców, działań mieszkańców oraz udziału w tych przedsięwzięciach turystów (a także „turystów” - jako powracających tu z różnymi intencjami byłych mieszkańców $\left.{ }^{26}\right)$. Refleksję zacząć można od „pierwszego wrażenia”, poświadczonego jednak wieloma opublikowanymi zapisami, rozmowami z mieszkańcami i turystami: o ile wizyta czytelników Schulza w Drohobyczu bywa niestety rozczarowująca, bo - mimo ogromnych postępów w tym względzie dzięki staraniom drohobyckich schulzologów - samego Schulza trudno tam odnaleźć, o tyle Czerniowce okazują się... oczarowujące. Oczywiste jest, że nie można tu porównywać samych miast, gdyż różna była ich historia i różne też ślady materialne po niej się zachowały. Istotniejsze jest pytanie, w którą stronę oba miasta zmierzają, powołując się na swych wielkich rodaków i wykorzystując ich (oraz w jaki sposób) do celów - w języku z innej nomenklatury rzecz ujmując - promocji miasta. Być może w jakiejś dalszej perspektywie, na przykład związanej już ściśle z Unią Europejską, dużo się w tej materii zmieni.

Jednak o Schulza nikt się specjalnie nie niepokoi, zawsze bowiem był czytany i tłumaczony, a admiratorzy jego twórczości odwiedzali (i odwiedzaliby) Drohobycz niezależnie od zmieniającego się miejskiego kontekstu. Uczestnicy czerniowieckich debat zgodnie twierdzili, że Schulz nie stanie się raczej ikoną pop-kultury. Natomiast pytanie w tej kwestii o Celana pozostaje otwarte. Potencjał Czerniowiec jest przeogromny, miasto bowiem, przynajmniej w swej głównej, zabytkowej części, a także w jej infrastrukturze przyjaznej gościom, w niczym nie ustępuje najczęściej i najchętniej odwiedzanym dziś miastom europejskim. Niepokój wynikać może z obserwacji chociażby turystycznie rozwijającej się Pragi, a przede wszystkim - jeśli można użyć takiego sformułowania - związanego z tym swoistego „efektu Kafki”. Oferty wycieczek po Pradze szlakiem Kafkowskich powieści, biletowanie odwiedzin domu na Złotej Uliczce, podobizna autora Procesu spoglądająca z każdego suweniru - znawcy twórczości i biografii Kafki wyczuwają tu wyraźny dysonans, i nie można z całą pewnością orzec, że podobny los nie spotka Celana. Już w tej chwili nie wszyscy pochwalają rozszerzającą się formułę poetyckiego festiwalu, a także jego komercjalizację, nieodłącznie związaną przecież z roszczeniami sponsorów, gustami i przekonaniami decydentów, potrzebami samych mieszkańców, wreszcie naturalną chęcią

${ }^{26}$ Por. M. Hirsch, L. Spitzer, Ghosts of Home. The Afterlife of Czernowitz in Jewish Memory, Berkeley - Los Angeles - London 2010.

Polonistyka. Innowacje

Numer 9, 2019 
szybkiego nadrobienia straconego $\mathrm{w}$ tej materii czasu $\mathrm{w}$ ramach rozwoju miasta i wzmacniania jego kulturowego potencjału. Pomiędzy pytaniami o to, co jest dobre dla miasta, a co dla samego pisarza (i jego prawdziwych czytelników), kryje się więc cały szereg wątpliwości.

Na razie można stwierdzić, że w dużym stopniu dzięki przypominaniu i wykorzystywaniu tradycji literackich Czerniowce są dzisiaj właściwie gotowe do zdecentralizowania mapy ${ }^{27}$ albo raczej: do ponownego zaistnienia na mapie Europy ${ }^{28}$ - jako ważne centrum europejskiej kultury, a nie tylko (jak dotychczas częściej bywało) mityczna, „literacka” kraina czy „niewidzialne miasto" dla wtajemniczonych czytelników hermetycznej poezji Paula Celana. Rozkwit kultury miejskiej Czerniowiec dzisiaj, świadome pisanie miasta oraz twórcze podejście do spodnich warstw palimpsestu są więc ściśle oparte na przeszłości. Przekłada się to wprost na tkankę miasta i jego „pocztówkową” promocję: od inicjatyw poszczególnych kawiarni czy sklepów z pamiątkami, aż po oficjalne pomysły, by remontowaną, okazałą kamienice Narodowego Banku Ukrainy zasłonić estetycznymi banerami z reprodukcjami pocztówek starych Czerniowiec.

Wspomniana wcześniej kinogoga, świątynia ormiańska jako miejsce koncertów organowych, zniszczony kościół katolicki jako do niedawna jeszcze zamknięte archiwum, wreszcie zaniedbana ulica Paula Celana, z którą nie miał on nic wspólnego, jego pomnik, niezbyt udany zarówno pod względem mimetycznym, jak i artystycznym, jego „pomyłkowy” dom (wyremontowano nie tę kamienicę), kolejne zmiany nazw ulic - wszystko to sprawia, że miejski palimpsest jest w ciągłym ruchu. W pewnym momencie historycznego rozwoju miasta wydawało się, że dawną wielokulturowość, po której zostały liczne ślady, ale która de facto uznana została w czasach powojennych za bezpowrotnie i słusznie minioną przeszłość, zastąpiło bardziej adekwatne pojęcie postsowieckości, gdyż rzeczywiście skutecznie historię Czerniowiec zatarto ${ }^{29}$. Dziś, po kolejnych kilku latach, wydaje się, że w bardzo wyrazisty sposób walczą ze sobą te dwa nurty - jeden zadany, związany z działalnością świadomych mieszkańców, artystów, animatorów kultury, części polityków, którzy za wszelką cenę (często za cenę być może nieuniknionej komercjalizacji dziedzictwa kulturowego) próbują przypomnieć dawne mity, zreinterpretować je, a także pisać nowe, na wzór dokonań miast Europy Zachodniej ${ }^{30}$. Drugi nurt określić można jako zastany - postsowiecki, dziś politycznie uwikłany, obejmujący przecież narzucone dziedzictwo kilku pokoleń mieszkańców „przemianowanego miasta", włącznie z dzielnicami zaniedbanych blokowisk, tak

${ }_{27}$ Por. E. Rybicka, Geopoetyka (o mieście, przestrzeni i miejscu we współczesnych teoriach i praktykach kulturowych), w: Kulturowa teoria literatury. Główne pojęcia i problemy, red. M.P. Markowski, R. Nycz, Kraków 2006, s. 481.

${ }^{28}$ Por. Czernowitz im Kontext der urbanen Prozesse Ostmitteleuropas vom 18. bis zum 20. Jahrhundert, red. M. Dippelreiter, S. Osatschuk, Czernowitz 2008.

29 Por. E. Polak, s. 50.

30 Por. Czernowitz tomorrow. Architecture and identity in the surge of central Eastern Europe, red. G. Zamp Kelp, J. Lienemeyer, Düsseldorf 2007. 
nieadekwatnych wobec zjawiskowej, odnowionej w ramach okrągłej rocznicy starówki. Z perspektywy wzgórza cmentarza żydowskiego, gdzie na ostatniej skarpie umieszczono najnowsze, skromne groby czerniowieckich Żydów, rozciąga się widok na tę właśnie część miasta, nieuwzględnianego w ramach turystycznych wycieczek i kulturowych badań, i nieświadomego często ani tego mitu, ani konfliktu.

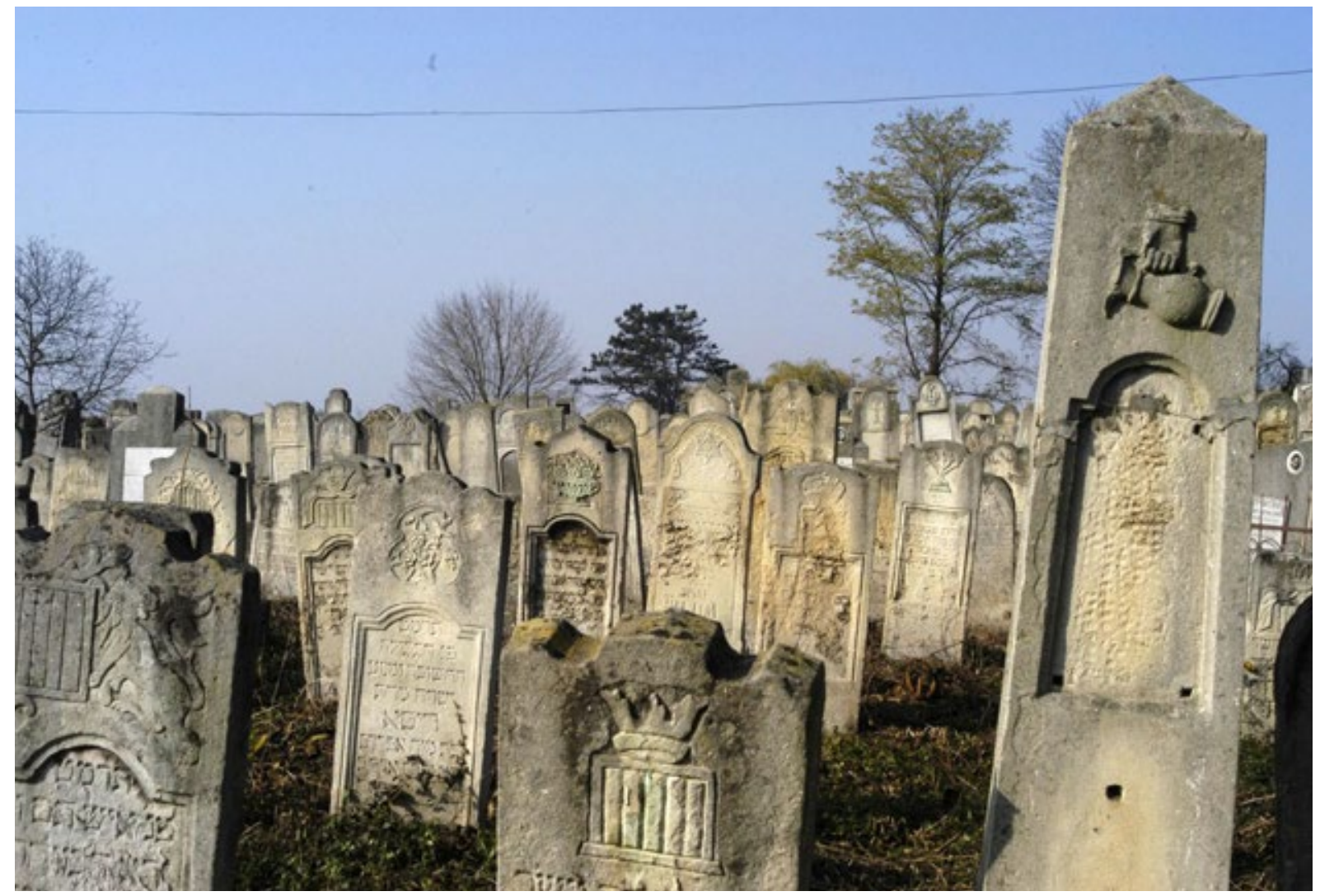

6. Cmentarz żydowski w Czerniowcach (fot. R. Koschany)

Symbolicznym obrazem-palimpsestem Czerniowiec pozostaje więc stary, ale wciąż czynny żydowski cmentarz. Na macewach i płytach nagrobnych zapisana została historia Czerniowiec - we wszystkich używanych tu językach i alfabetach. Zaniedbanie i "ciasnota”"31 utrudniają lekturę, ale jednocześnie pozwalają na fascynującą przygodę podczas rozczytywania spodnich warstw tekstu. „Nic w naszej części Europy - pisał w tym kontekście Andruchowycz - tak nie cierpi w wyniku zmian cywilizacji i systemów jak cmentarze. Budynkom jest łatwiej - mogą zostać przejęte i zasiedlone. Ale komu będzie się chciało dbać o cudze nagrobki, czytelność palestyńskich znaków? Dlatego cmentarz to zawsze poemat epicki, księga z nazbyt wielką liczbą bohaterów i postaci, w dodatku zupełnie nienadająca się do czytania, jeśli jest to cmentarz żydowski”.

${ }^{31}$ Dopiero tutaj, w natłoku i ścisku chylących się ku ziemi macew, niemalże cieleśnie można doświadczyć frazy z Celanowskiej Fugi śmierci: „Grób kopiemy w powietrzu tam się nie leży ciasno”; P. Celan, Fuga śmierci, przeł. S.J. Lec, w: Utwory wybrane, op. cit., s. 25. 


\section{O Autorze:}

Rafał Koschany - dr hab., adiunkt w Zakładzie Semiotyki Kultury Instytutu Kulturoznawstwa Uniwersytetu im. Adama Mickiewicza w Poznaniu, redaktor naczelny czasopisma „Kultura Współczesna”. Swoje zainteresowania badawcze skupia na teorii interpretacji, pograniczu literaturoznawstwa i filmoznawstwa, kulturowych studiach miejskich oraz edukacji kulturowej. Autor książek Przypadek. Kategoria artystyczna i literacka $w$ literaturze i filmie $\left(2006,2016^{2}\right)$ i Zamiast interpretacji. Między doświadczeniem kinematograficznym a rozumieniem filmu (2017), a także licznych artykułów publikowanych w czasopismach naukowych oraz tomach zbiorowych. Współredaktor kilku książek, m.in.: Horyzonty interpretacji. Wokół myśli Paula Ricoeura (2003), Fenomen słowa (2009), Musical. Poszerzanie pola gatunku (2013). 